\title{
The Antibody Response against HIV-1
}

\author{
Julie Overbaugh ${ }^{1}$ and Lynn Morris ${ }^{2}$ \\ ${ }^{1}$ Division of Human Biology, Fred Hutchinson Cancer Research Center, Seattle, Washington 98109 \\ ${ }^{2}$ AIDS Virus Research Unit, National Institute for Communicable Diseases, Johannesburg 2131, South Africa \\ Correspondence: joverbau@fhcrc.org
}

Neutralizing antibodies (NAbs) typically play a key role in controlling viral infections and contribute to the protective effect of many successful vaccines. In the case of HIV-1 infection, there is compelling data in experimental animal models that NAbs can prevent HIV-1 acquisition, although there is no similar data in humans and their role in controlling established infection in humans is also limited. It is clear HIV-specific NAbs drive the evolution of the HIV-1 envelope glycoprotein within an infected individual. The virus's ability to evade immune selection may be the main reason HIV-1 NAbs exert limited control during infection. The extraordinary antigenic diversity of HIV-1 also presents formidable challenges to defining NAbs that could provide broad protection against diverse circulating HIV-1 strains. Several new potent monoclonal antibodies (MAbs) have been identified, and are beginning to yield important clues into the epitopes common to diverse HIV-1 strains. In addition, antibodies can also act in concert with effector cells to kill HIV-infected cells; this could provide another mechanism for antibody-mediated control of HIV-1 replication. Understanding the impact of antibodies on HIV-1 transmission and pathogenesis is critical to helping move forward with rational HIV-1 vaccine design.

\begin{abstract}
A ntibodies have the potential to block HIV-1 Areplication through multiple pathways, and they exert immune pressure on the virus that leads to escape. Neutralizing antibodies (NAbs) bind cell-free virus and prevent the virion from infecting the host target cells, thereby disrupting subsequent rounds of replication (Fig. 1A). HIV-1 specific antibodies can also complex with the Fcy receptor to counter HIV-1 through effector cell mechanisms-a process that has the potential to contain cellcell HIV-1 spread (Fig. 1B,C). It is not possible to predict which of these antibody mechanisms will be most effective in containing HIV-1
\end{abstract}

because the relative contribution of cell-free versus cell-cell spread in HIV-1 transmission and pathogenesis is not well defined. Thus, the ability of antibodies to block HIV-1 infection by each of these pathways is the topic of intense study.

Current efforts to identify protective HIV-1 vaccine immunogens are focused primarily on those that elicit broadly NAb responses (Fauci et al. 2008), inspired by the results of experimental studies in macaques showing that passively transferred NAbs can protect against viruses related to HIV-1 (see Lifson and Haigwood 2011). However, as discussed below, the

Editors: Frederic D. Bushman, Gary J. Nabel, and Ronald Swanstrom

Additional Perspectives on HIV available at www.perspectivesinmedicine.org

Copyright (C) 2012 Cold Spring Harbor Laboratory Press; all rights reserved; doi: 10.1101/cshperspect.a007039

Cite this article as Cold Spring Harb Perspect Med 2012;2:a007039 
J. Overbaugh and L. Morris

A Neutralization

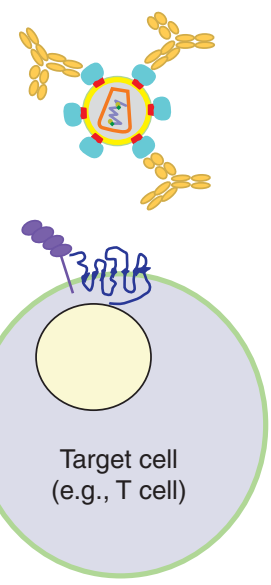

B

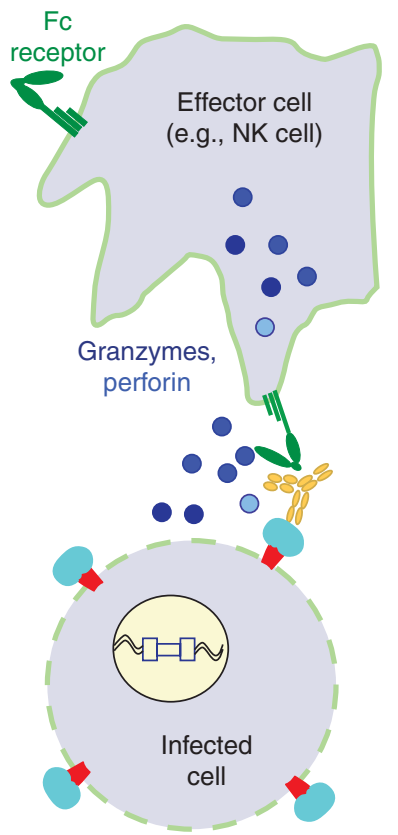

C

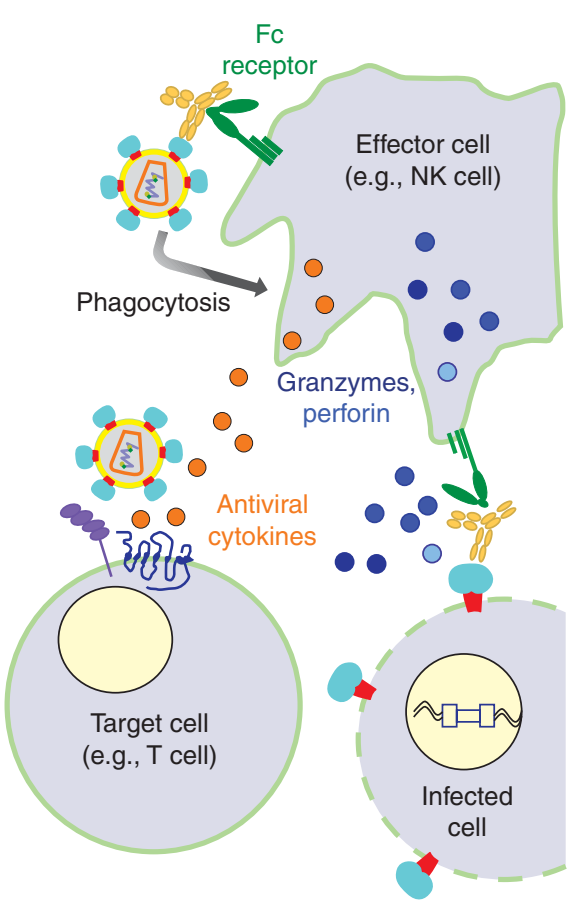

Figure 1. Schematic representation of the mechanism of action of NAbs and antibodies that act through ADCC and ADCVI. (A) Antibody neutralization of cell-free virus. Neutralizing antibodies bind to HIV-1 envelope glycoproteins and block the interaction of viral particles with CD4 and CCR5, essential receptors on target cells required for infection. $(B)$ Antibody-dependent cellular cytotoxicity leads to the killing of infected cells. In the case of ADCC, a complex between the IgG Fab portion of antibody bound to envelope protein on the cell surface and the Fc portion to the Fc receptors on effector cells leads to lysis of the infected cell. $(C)$ Antibodydependent cell-mediated virus inhibition. ADCVI measures the effects of ADCC-mediated cell killing, which lead to reduced virus production, as well as virus inhibition by antiviral cytokines and other secondary effects of FcR-virus interactions such as phagocytosis.

ability of NAb to provide protection from HIV-1 infection and/or disease progression in humans still remains poorly defined.

Here we review what is known about the role of antibodies in driving virus escape, in controlling an established infection, and in preventing new infections. Much of the article focuses on the neutralizing function of antibodies, including recently discovered HIV-specific broadly neutralizing monoclonal antibodies (MAbs), because antibodies capable of neutralizing cell-free virus infections have garnered the most attention in the HIV-1 field. However, there is increasing interest in antibodies that act through effector mechanisms, and a summary of this topic is included. This article will focus on studies of HIV-1 in humans but seminal studies in the nonhuman primate model that clarify important issues will be noted where relevant. A more complete review of the related studies in the nonhuman primate model can be found in Lifson and Haigwood (2011).

\section{EARLY ANTIBODIES AND VIRAL ESCAPE}

B cell responses to HIV-1 infection first develop within $\sim 1$ week of detectable viremia, and initially are detected as antigen-antibody complexes (Tomaras et al. 2008). This phase is followed by circulating anti-gp41 antibodies a few days later, with anti-gp120 antibodies delayed a further few weeks and primarily 
targeting the V3 loop. However, these binding antibodies have no detectable effect on viremia (Tomaras et al. 2008) and apparently do not exert any selective immune pressure on the envelope (Keele et al. 2008). NAbs against the infecting strain (autologous virus) appear months later but are not able to neutralize more divergent viruses isolated from other individuals (heterologous viruses) (Moore et al. 1994; Legrand et al. 1997; Moog et al. 1997; Pilgrim et al. 1997; Richman et al. 2003; Wei et al. 2003; Frost et al. 2005; Deeks et al. 2006; Gray et al. 2007). These autologous NAbs drive neutralization escape as evidenced by the fact that contemporaneous viruses are less sensitive to autologous neutralization than earlier viruses, although later viruses remain sensitive to new NAb responses. Escape occurs through single amino acid substitutions, insertions and deletions, and through an "evolving glycan shield," in which shifting glycans prevent access of NAbs to their cognate epitopes (Overbaugh and Rudensey 1992; Chackerian et al. 1997; Herrera et al. 2003; Richman et al. 2003; Wei et al. 2003; Bunnik et al. 2008).

Recent data suggest that autologous responses in the first year of infection comprise one or two antibody specificities targeting variable regions of the HIV-1-envelope glycoprotein (Moore et al. 2009a; Rong et al. 2009). These potent but highly type-specific antibodies appear sequentially and show temporal fluctuations as escape variants emerge. It has been proposed that an immunological hierarchy of NAb responses exists, similar to what is seen for binding antibodies (Moore et al. 2009a). Alternatively, stimulation of new specificities may occur as additional epitopes become immunodominant on the escape variants. If so, this may ultimately in some instances, result in the exposure of more conserved regions that will lead to the induction of broadly crossneutralizing antibodies in some individuals (Moore et al. 2009a).

A major target of autologous NAbs is the V1V2 region, which can serve both as a direct antibody target but also, as a result of its location and extensive glycosylation, act as a shield for other vulnerable sites (Pinter et al. 2004; Rong et al. 2007). This was first shown in the $\mathrm{SIV} /$ macaque model, where the earliest genetic changes were in V1V2 (Burns and Desrosiers 1991; Johnson et al. 1991; Overbaugh et al. 1991; Overbaugh and Rudensey 1992; Laird et al. 2008) and biochemical studies showed that the addition of $\mathrm{N}$ - and O-linked carbohydrates was a key pathway of NAb escape (Chackerian et al. 1997). In HIV-1 subtype C infection, the $\mathrm{C} 3$ region and specifically the $\alpha 2$-helix is also a major target of autologous NAbs that may be related to the more amphipathic nature of the subtype $\mathrm{C} \alpha-2$ helix in combination with a shorter V4 loop (Gnanakaran et al. 2007; Rong et al. 2009). The V1V2 as well as sites at the base of the V3 loop have been shown to be targets of autologous NAbs in HIV-1 subtype B (Fig. 2). In particular, a glycan at the base of the V3 which contributes to the 2G12 epitope was identified in two subtype $\mathrm{B}$ infected individuals as mediating autologous NAb escape (Tang et al. 2011). Despite the strain-specificity and their transient effect, studies on autologous NAbs are important because they identify vulnerable immunogenic regions of the HIV-1 envelope glycoprotein.

\section{DEVELOPMENT OF BROADLY CROSS-NEUTRALIZING ANTIBODIES}

NAbs tend to increase in potency over time and broadly cross neutralizing (BCN) responses, capable of recognizing heterologous HIV-1 variants, develop in a subset of individuals after primary infection (Moore et al. 1996; Moog et al. 1997; Beirnaert et al. 2000; Binley et al. 2008; Piantadosi et al. 2009; Sather et al. 2009; Simek et al. 2009; Gray et al. 2011). The reasons why some individuals develop BCN antibodies is unclear but is related to the duration of infection and viral levels suggesting that years of persistent viral stimulation are necessary for their generation (Piantadosi et al. 2009; Sather et al. 2009; Euler et al. 2010; Gray et al. 2011). However, the finding that not all individuals develop $\mathrm{BCN}$ antibodies points to the role of additional factors that could be viral or host or most likely an interplay between the two. There is some 
J. Overbaugh and L. Morris

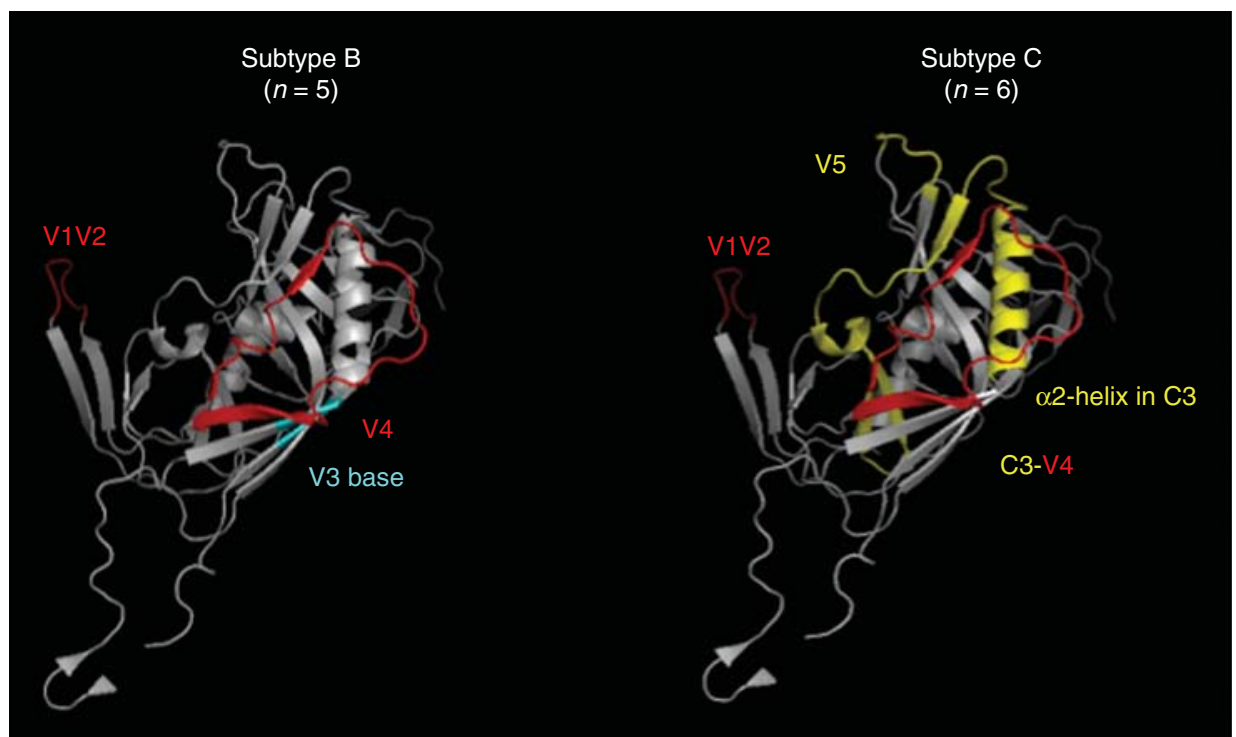

Figure 2. Targets of autologous NAbs on HIV-1 subtype B and subtype C envelopes. The figure summarizes data from studies in which the precise targets of autologous NAbs on gp120 have been defined. This includes two studies in HIV-1 subtype B infection (KJ Bar, unpubl.; Tang et al. 2011) and two in HIV-1 subtype C infection (Moore et al. 2009; Rong et al. 2009). The sites targeted are listed in color with the corresponding regions on the gp120 structures in the same color. Sites are highlighted on the crystal structure of HIV-1 JR-FL gp120 core protein containing the third variable region (V3) complexed with CD4 and the X5 antibody (PDB 2B4C) (Huang and Tang 2005).

evidence that viral genetic subtype may also be important as the breadth and potency of humoral responses is reported to be higher in subtype $\mathrm{C}$ and $\mathrm{A}$ than in subtype $\mathrm{B}$ infections (Bures et al. 2002; Li et al. 2006; Brown et al. 2008; Dreja et al. 2010).

A large number of studies published in the last few years have described the presence of BCN antibodies in different cohorts. These have been important studies as they indicate that such sera and antibodies are not rare (Stamatatos et al. 2009). Although there is no standard definition of breadth, all studies identified a proportion $(\sim 30 \%)$ of individuals with BCN antibodies based on their ability to neutralize a significant number of heterologous viruses usually of multiple genetic subtypes. In some cases, the specificities of the antibodies conferring breadth have been mapped and are reactive with conserved envelope regions, as exemplified by well-characterized neutralizing MAbs IgG1b12 (anti-CD4bs), 4E10 (carboxy-terminal MPER), 2F5 (amino-terminal MPER), and
2G12 (glycan array on gp120 outer domain). The ability of recombinant proteins and peptides to deplete neutralizing activity was a major step toward unraveling the components of these complex plasma/sera and the use of mutant proteins allowed for mapping to the CD4bs (Dhillon et al. 2007; Binley et al. 2008; Gray et al. 2009b; Li et al. 2009; Sather et al. 2009) or to CD4 induced epitopes (CD4i) (Gray et al. 2009b; Li et al. 2009). In other cases, neutralizing activity could be mapped to linear epitopes within the membrane proximal region (MPER) of gp41 (Binley 2009; Gray et al. 2009a,b; Li et al. 2009; Sather et al. 2009). As new NAb epitopes are discovered, mapping tools are expanding to detect these specificities. Thus, PG9/16-like antibodies are frequently being identified in BCN sera (Fig. 3). However, not all the BCN activities have been accounted for, suggesting that additional important neutralizing epitopes on the HIV-1 envelope glycoprotein are yet to be discovered. Collectively, these studies provide evidence that the human 
A

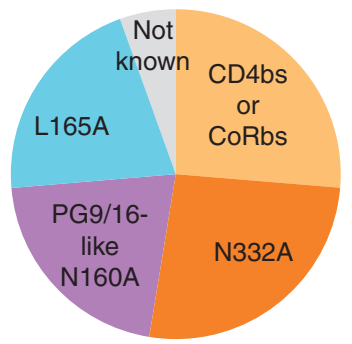

B

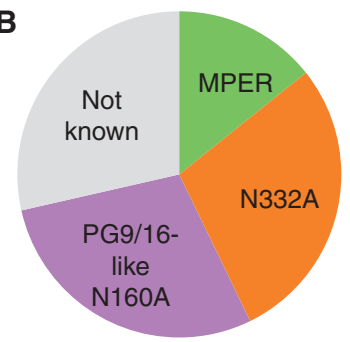

C

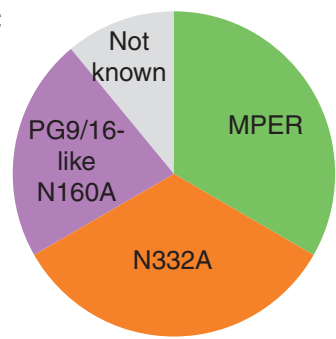

Figure 3. Specificity of antibodies in cross-neutralizing samples. Summary of the three most comprehensive mapping studies to date examining the specificities of antibodies mediating neutralization breadth. This includes (A) 19 samples from Walker et al. (2009), (B) seven samples from Gray et al. (2011), and (C) nine samples from Tomaras et al. (2010). PG9/16-like NAbs and an undefined epitope that involves a glycan at position 332 in the outer domain of gp120 were the most common targets in all three studies. Antibodies found to be responsible for breadth in fewer samples included those targeting the MPER $(B, C)$ or CD4bs/CoRbs $(A)$. In all three studies the antibody specificities in some of the broadly cross-neutralizing sera/plasma could not be identified.

immune system can generate BC NAbs against HIV-1. Intensive efforts are underway by many laboratories to isolate MAbs from these individuals (see section on MAbs later) as this may lead to the identification of new sites on the HIV envelope that could serve as targets for vaccine induced immune responses.

The question of whether breadth is conferred by single or multiple specificities has in part been addressed by some of these studies. Certainly, cases of multiple specificities have been documented, but there is also evidence that single MAbs can account for the breadth displayed by $\mathrm{BCN}$ plasma, most recently through the isolation of VRC01, a highly potent and broad anti-CD4bs $\mathrm{mAb}$ from an individual whose plasma neutralizing activity was shown to have anti-CD4bs activity (Wu et al. 2010). On the other hand, a study by Nussensweig and colleagues suggested that neutralization breadth is the result of multiple antibody specificities, each one targeting a few viral variants (Scheid et al. 2009). For vaccine design, it would likely be considerably more challenging to induce multiple rather than single specificities because different antigens and thus a more complex vaccine would be required to stimulate a polyclonal response.

Another important question is whether escape from BCN antibodies occurs as readily as it does from autologous NAbs. There is less data on this but one might imagine that because $\mathrm{BCN}$ antibodies target more conserved sites, escape would be more difficult to achieve. Certainly, this is suggested in cases in which contemporaneous neutralization is seen more frequently among plasma with BCN activity (Mahalanabis et al. 2009; Bosch et al. 2010; Kirchherr et al. 2011). However, cloned viruses from the individual who was the source of VRC01, the highly potent anti-CD4bs mAb that targets one of the most conserved regions on the envelope glycoprotein, were resistant to this MAb (Wu and Wang 2010). Studies on MAbs and polyclonal plasma are difficult to compare as the lack of escape from polyclonal plasma may be the result of multiple somatic variants of a neutralizing specificity which target different variants within the quasispecies (Morris and Chen, submitted).

The development of neutralization breadth may include a requirement for extensive somatic mutational diversification that may be impeded by the B cell dysfunction that occurs in HIV-1 infection (Moir and Fauci 2009). A role for affinity maturation in the ontogeny of anti-HIV-1 neutralizing capacity is supported by Toran and coworkers (Toran et al. 1999), who showed that all anti-gp120 NAbs in a long-term nonprogressor were clonally related with considerable somatic hypermutation. Furthermore, immunogenetic analysis of 
existing MAbs suggests that they have undergone multiple rounds of affinity maturation to achieve BCN activity (Zhou et al. 2007; Walker et al. 2009; Xiao et al. 2009). These MAbs are characterized by unusual physical features such as heavy chain domain-swapping, sulphated tyrosines, long and hydrophobic CDRH3's, and high levels of hypermutation (Burton et al. 2005; Kwong and Wilson 2009). Whether these events are required for antibodies to mediate cross-reactivity is not known, and longitudinal studies of immunoglobulin genes among those individuals who develop breadth are needed to understand how the immune system can generate such antibodies. If indeed longterm antigenic exposure is required, vaccination strategies will need to be revised to not only consider the immunogen used, but to incorporate the required number of booster and/or antigen exposures needed to reach the required level of antibody affinity.

\section{ANTIBODIES AND DISEASE PROGRESSION}

Several studies have examined whether HIV-1specific NAbs contribute to viral control. The first studies focused primarily on select populations, such as long-term nonprogressors (LTNP) but these were conflicting, with some providing evidence that NAb contributed to control of infection (Cao et al. 1995; Montefiori et al. 1996; Pilgrim et al. 1997; Zhang et al. 1997; Carotenuto et al. 1998; Cecilia et al. 1999), others suggesting the opposite-that NAbs responses were low in LTNPs (Pereyra et al. 2008; Doria-Rose et al. 2009; Lambotte et al. 2009), and still others not finding consistent evidence for or against a role for NAb in controlling infection in LTNPs (Harrer et al. 1996; Barker et al. 1998; Loomis-Price et al. 1998; Bailey et al. 2006).

The first studies of more typical HIV-1infected populations showed that individuals with greater NAb breadth had higher contemporaneous viral loads, suggesting that antigenic stimulation could be key to eliciting these NAbs (Deeks et al. 2006; Rodriguez et al. 2007; Pereyra et al. 2008; Doria-Rose et al. 2009; Sather et al. 2009). Recent studies, focused on populations followed from the time of infection, showed that the association of NAb breadth and contemporaneous viral load in chronic infection was not significant after controlling for set point viral levels, suggesting that higher viral replication was a cause, rather than a consequence of NAb breadth (Piantadosi et al. 2009). In addition, it was found that greater envelope diversity early in infection contributed to the breadth of the subsequent NAb responses, further suggesting that antigenic stimulation drives NAb breadth. Importantly, these longitudinal studies showed that the breadth of the NAb did not impact progression to AIDS (Piantadosi et al. 2009; Euler et al. 2010; Gray et al. 2011) suggesting that the presence of broad NAbs in and of itself did not lead to viral control. This finding was consistent with findings from studies of passively administered, broadly neutralizing antibodies in chronic HIV-1 infection, in which it was estimated that antibody levels that were 10- to 100 -fold higher than those already present in chronic HIV-1 infection would be required to see clinical benefit of monoclonal antibody therapy (Trkola et al. 2008).

Although these studies collectively suggest that the breadth of the NAb response, as measured against heterologous virus panels, does not correlate with viral control or pathogenecity, it is important to note that most have not addressed whether NAb specifically targeted to the virus in that individual provide clinical benefit. A recent case report, showing a drop in viral load coincident with the detection of NAb that recognizes the autologous virus, suggested the possibility that autologous NAb have the potential to contribute to viral control, although escape and loss of viral control is rapid (Moore et al. 2009b).

Another case report of a HIV-1-positive individual who underwent a $\mathrm{B}$ cell depletion protocol as part of clinical care unrelated to HIV-1 also showed a temporal relationship between changes in the autologous NAb response and viral levels, although viral load changes from other effects of B cell depletion could not be ruled out (Huang et al. 2010). These results are consistent with the results of $\mathrm{B}$ cell depletion studies in the SIV/rhesus 
macaque model (Schmitz et al. 2003; Miller et al. 2007, and see Lifson and Haigwood 2011). In addition, one cross-sectional population study suggested that, unlike heterologous NAb responses, autologous NAb inversely correlate with viral levels; however, in this study there was limited follow-up, and longer term clinical outcomes measures were not available (Deeks et al. 2006). Thus, it is possible that $\mathrm{NAb}$ are exerting some control on virus replication, but detailed studies of autologous NAb responses in relation to clinical outcome in longitudinal cohorts are needed to clarify whether NAbs exert any control on HIV-1 infection.

\section{ANTIBODIES AND TRANSMISSION}

Because effective protection afforded by most vaccines correlates with antibody responses (Karlsson Hedestam et al. 2008), there is considerable interest in determining whether NAbs can protect against HIV-1 transmission, and if so, in defining the NAb levels and specificities required for protection. As discussed by Lifson and Haigwood (2011), passively infused NAbs can block SIV and SHIV-1 infection in the nonhuman primate model (Prince et al. 1991; Emini et al. 1992; Conley et al. 1996; Mascola et al. 1999, 2000; Shibata et al. 1999; Baba et al. 2000; Parren et al. 2001; Mc Cann et al. 2005; Hessell et al. 2009). However, in most of the initial, proof-of-principle passive antibody studies, the antibody levels used to achieve protection were high, and typically the virus strain used for challenge was very sensitive to neutralization by the antibody tested. In more recent studies, lower NAb levels, closer to those found in HIV-1 infected humans, were shown to increase the number of exposures required to achieve infection (Hessell et al. 2009). In this study, the viral challenge strain was highly sensitive to the NAb, making it hard to extrapolate from these findings to predict an effective dose in humans, who are exposed to diverse HIV-1 strains that can differ by several orders of magnitude in their neutralization sensitivity (Blish et al. 2009; Walker et al. 2009; Seaman et al. 2010). There are limited studies from exposed humans that can inform our understanding of the potential of HIVspecific antibodies to protect against these diverse, circulating strains of HIV-1, and these studies primarily have focused on exposed infants and individuals who become superinfected. In both of these cases, HIV-1-specific NAbs are present at the time of virus exposure.

HIV-infected high-risk individuals often continue to be exposed to HIV-positive partners and thus are at risk of being superinfected (reinfected) (reviewed in Chohan et al. 2010). Cases of superinfection have provided the chance to examine whether there are particular deficits in HIV-1 immunity in individuals who become superinfected versus those who do not despite similar continued exposure. The first study of NAbs in cases of superinfection suggested that individuals who become superinfected $(N=3)$ had relatively weak NAbs compared to controls (Smith et al. 2006). However, this study examined responses to only three viral strains, and at an early time after the first infection when NAbs tend to be weak in general. A second study focusing on six cases of superinfection, including cases that occurred several years after the first infection, showed that the neutralizing antibody breadth, defined using a panel of 16 circulating recently transmitted viral variants, was similar in individuals who became superinfected to NAb breadth in individuals who did not become superinfected (Blish et al. 2008). Furthermore, the antibodies that were present near the time of superinfection could neutralize the strain that established the second infection in most cases (Blish et al. 2008), suggesting that reinfection occurred in the face of NAbs that recognized the incoming variant. These studies suggest that the level of antibody elicited during chronic HIV-1 infection may not be adequate to protect against reinfection by diverse HIV-1 variants; however, studies to-date have been small.

The setting of mother-to-child transmission (MTCT) also offers a chance to explore whether Nab, present at the time of exposure, protects against HIV-1 infection in humans. Very few studies have focused specifically on the role of passively acquired antibodies in the exposed infant in protection, although one 
recent study showed that uninfected infants of HIV-1-positive mothers have HIV-1-specific NAb levels at birth that are comparable to those in an infected individual (Lynch et al. 2011). However, there was no evidence that the breadth or potency of infant antibodies, defined using a heterologous virus panel, correlated with protection from infection during the breastfeeding period (Lynch et al. 2011). Nonetheless, studies of maternal NAb do provide some support for a protective role for NAb in the mother, who in this situation is the index case. These studies have focused primarily on the study of maternal autologous virus, which is a more direct test of the potential of the antibodies to neutralize the specific virus that the infant encounters than the study of virus panels. Most of these studies suggest that mothers with more potent autologous NAbs are less likely to transmit to the infant than mothers with low autologous NAb levels (Scarlatti et al. 1993a,b; Kliks et al. 1994; Dickover et al. 2006). However, the results of studies of the effect of maternal NAb on transmission have reached divergent conclusions as to whether NAbs are important during all stages of mother-to-child transmission (in utero, intrapartum, and breastfeeding); for example, one study suggested a protective effect of NAb only for intrapartum transmission (Barin et al. 2006; Samleerat et al. 2009), whereas two others suggest NAb protection only in utero transmission (Dickover et al. 2006). Moreover, some studies have reported no association of maternal NAbs and infant infection (Husson et al. 1995; Hengel et al. 1998). These divergent findings could reflect methodological differences, such as the relative timing of the NAb and viruses studied, which is critical given the rapid evolution of both virus and antibody responses (Burton et al. 2005), whether the study examined autologous or heterologous responses and the assays used, as well as the sample size of the study, which in the earliest studies was typically small. However, to date, no specific study design differences have been identified to explain these variable findings. Although most of the larger studies do show a positive association between maternal antibodies and protection from HIV-1 infection in the infant, this remains a critical issue to resolve fully.

In MTCT, as in other modes of HIV-1 infection, only one or a few HIV-1 variants are transmitted (reviewed in Sagar 2010 and discussed more fully in Shaw and Hunter 2011). However, there are interesting differences in neutralization sensitivity among viruses transmitted sexually compared to vertically. One detailed study of sexually transmitted viruses suggested that they are generally more neutralization sensitive compared to the population of viruses in the source partner (Derdeyn et al. 2004). In sexual transmission, immune selection pressure is not expected to play a role because HIV-1specific NAb is not likely to be present in the exposed individual, which is in contrast to the setting of MTCT. Similar studies of individual variants isolated from mother-infant transmission pairs showed that the transmitted variants tended to be among the more neutralizationresistant viruses compared to the maternal viruses (Wu et al. 2006; Zhang et al. 2010). Although antibodies present in some transmitting mothers did neutralize the variants transmitted to their infants, the most highly neutralization-sensitive maternal variants were generally not transmitted (Wu et al. 2006; Zhang et al. 2010). Thus, the studies of MTCT support the notion that there may be some level of NAb protection, at least against the most neutralization-sensitive viruses, raising the possibility that higher levels of broadly crossreactive $\mathrm{NAb}$ than those present in natural infection could prevent infection by more diverse variants.

There have also been studies suggesting a protective effect of NAbs in highly HIV-1exposed, uninfected individuals (Hirbod et al. 2008; Hasselrot et al. 2009). These studies, although intriguing, remain controversial because there is limited precedent to suggest that antibodies are elicited by exposure in the absence of viral infection. However, the more frequent detection of this HIV-1-neutralizing activity from exposed uninfected population compared to controls has now been shown in several cohorts (Hirbod et al. 2008; Hasselrot et al. 2009). The activity was detected in the 
The Antibody Response against HIV-1

IgA antibody fraction, but the nature of this neutralizing activity remains to be defined.

\section{IDENTIFICATION AND CHARACTERIZATION OF MONOCLONAL ANTIBODIES}

HIV-1-specific monoclonal antibodies (MAbs) have been exceptionally useful reagents for characterizing neutralization-sensitive targets on the HIV-1 envelope glycoproteins and for revealing the structural dimensions of this complex heterotrimer. One of the first MAbs to be extensively used for this purpose was IgG1b12, which was isolated in 1994 and targets the CD4 binding site (CD4bs). The CD4bs represents one of the most attractive targets for vaccine-induced immune responses because it is a highly conserved site present on all HIV-1 genetic subtypes as a result of the absolute requirement for engaging the $\mathrm{CD} 4$ molecule to gain entry into human cells. Recently, VRC01, which is a considerably more potent anti-CD4bs MAb, has provided additional insights into the nature of this epitope (for additional information see Kwong et al. 2011). A cluster of new antibodies have helped to define a highly structural epitope present only on the trimeric envelope that includes conserved regions of both V2 and V3. The first identified $\mathrm{MAb}$ directed to this target, $\mathrm{MAb}$ 2090, was type-specific and neutralized only SF162 because this isolate carries an unusual lysine at position 160 in V2 (Honnen et al. 2007). PG9/16 isolated from a subtype A chronically infected individual with exceptional plasma neutralization breadth binds the more common N160 variant and are hence more broadly cross-reactive (Walker et al. 2009). These types of antibodies have been isolated from other individuals with breadth (Bonsignori et al. 2010), and additional antibodies with different fine specificities await isolation (Tomaras et al. 2010; Gray et al. 2011). The 2G12 MAb, which was isolated in 1996 (Trkola et al. 1996), focused attention on glycans. The recent discovery of new MAbs that target the glycan at position 332 and compete with $2 \mathrm{G} 12$, but display more breadth and potency than $2 \mathrm{G} 12$, suggests that interest in this potential target is likely to increase (Walker et al. 2010). MAbs against the gp41 and the MPER have also recently been described and all define new epitopes in this region (Corti et al. 2010; Sabin et al. 2010; Zhu et al. 2010; L Morris and S Chen, submitted). One of the interesting aspects of this new era in MAb isolation is that all studies have isolated multiple highly mutated clonally related antibodies (Scheid et al. 2009; Walker et al. 2009; Bonsignori et al. 2010; Wu et al. 2010), underscoring the importance of the affinity maturation process that takes place in the development of antienvelope Abs.

A few studies have shown a skewed germline gene usage among HIV-1 MAbs. Those that target CD4i frequently use the 1-69 variable heavy chain gene family $\left(\mathrm{V}_{\mathrm{H}} 1-69\right)$ (Huang et al. 2004). It has been proposed that the two hydrophobic residues at the tip of the CDR-H2 loop in the $\mathrm{V}_{\mathrm{H}} 1-69$ germline genes allows the Ab to access hydrophobic recessed pockets such as the CD4i epitope and the MPER. In contrast, antiV3 MAbs appear to preferentially use the $\mathrm{V}_{\mathrm{H}} 5$ 51 germline gene (Gorny et al. 2009). These studies suggest that particular epitopes select for certain characteristics in the antibodybinding site that might only be provided by certain germlines. More studies with additional MAbs are needed to determine the full extent of this and whether vaccination strategies will need to select for B cells bearing specific immunoglobulin genes.

\section{NONNEUTRALIZING ANTIBODIES}

There is renewed interest in the potential role of nonneutralizing antibodies in control of HIV-1 infection. An important mechanism by which nonneutralizing antibody can clear virus is to bind to infected cells and recruit activated effector cells, which in turn induce cytolysis or apoptosis of infected cells. Antibody-dependent cellular cytotoxicity (ADCC) is the result of the formation of a complex between the IgG Fab portion of the antibody with the viral protein on the cell surface and binding of the Fc portion to the Fc receptors (Fc $\gamma$ Rs), on effector cells (see Fig. 1B). Potential 
effector cells include NK cells, macrophages, dendritic cells, $\gamma \delta$ T-cells, and neutrophils. In addition to causing cytolysis of the infected cell (Kagi et al. 1994), binding to the Fcy receptors can lead to release of antiviral cytokines (Berke 1995; Russell and Ley 2002), depending on the nature of the receptor. Thus, Fc receptormediated antibody activities can inhibit virus spread in multiple ways, and it can be measured as either a cytotoxic effect on infected cells (e.g., ADCC) or as virus inhibition (antibody-dependent cell-mediated virus inhibition, ADCVI), which measures not only virus reduction because of cell killing, but also virus inhibition by antiviral cytokines and other secondary factors (Fig. 1B). ADCVI may reduce the spread of both cell-free and cell-associated virus.

There is some evidence from vaccine studies in both humans and nonhuman primate model systems that nonneutralizing antibodies may afford some protection from infection. In human vaccine studies, a correlation was observed between both antibody binding activity and ADCVI antibody activity and the incidence of HIV-1 infection in vaccine recipients in the Vaxgen Phase III efficacy trial (Gilbert et al. 2005; Forthal et al. 2007a). One important caveat to this finding is that there was no overall protective vaccine effect of the vaccine. However, several vaccine challenge studies in rhesus macaques have shown that ADDC/ADCVI activity correlates with reduced viral load postchallenge (Banks et al. 2002; Gomez-Roman et al. 2005; Florese et al. 2009; Hidajat et al. 2009; Xiao et al. 2010). Perhaps the most compelling evidence for a protective role for antibodies that work through ADCC/ADCVI comes from passive immunization showing that a HIV-specific $\mathrm{MAb}$ engineered with decreased Fc $\gamma \mathrm{R}$ binding potential provided only partial protection compared to the original MAb, despite having similar neutralizing activity against the challenge virus (Hessell et al. 2007). These studies suggested that $\mathrm{Fc} \gamma \mathrm{R}$ function is important in the protective effect of the MAb tested (IgG1b12), perhaps by reducing cell-cell virus spread.

Studies of the role of Fc receptor-mediated antibody activities in HIV-1 disease progression have been relatively few compared to studies of
NAbs and CD8 T cell responses. Antibodies capable of ADCC/ADCVI have been detected early in infection, and a higher magnitude of Fc-mediated NK cell responses early correlated with lower set-point viral load (Connick et al. 1996; Forthal et al. 2001a,b); however, longterm follow-up was not available to determine associations with clinical outcome. Additional indirect support for a specific role of ADCC/ ADCVI in HIV-1 pathogenesis comes from studies of host genes that encode the Fc receptor proteins. Mutations in FcR impact IgG subclass binding affinity to the receptor, and thus may modulate ADCC/ADCVI responses. FcyRIIa genotype has been associated with the rate of $\mathrm{CD}^{+}$cell count decline in infected adults (Forthal et al. 2007b). FcyRIIa genotype in infants has also been linked with risk of infection, suggesting that $\mathrm{Fc}$ receptor interactions with passively acquired HIV-1-specific antibodies could be playing a role in infant infection (Brouwer et al. 2004). However, to date, there have been no studies demonstrating an association between ADCC/ADCVI in infants and their risk of HIV-1 acquisition.

\section{CONCLUSION}

There have been significant advances in the last few years that have renewed enthusiasm in the field and provided new insights into the nature of neutralizing antibodies. The finding that low doses of neutralizing MAbs at levels close to those found in natural infection can protect against neutralization-sensitive challenge strains via the mucosal route in monkeys (Hessell et al. 2009) may provide clues to the amount and specificity of antibody needed for protection. The virus targets are also becoming more extensively characterized; many studies have shown that transmission is mediated in most cases by just one or a few viral particles (McNearney et al. 1992; Wolinsky et al. 1992; Zhang et al. 1993; Zhu et al. 1993; Poss et al. 1995; Long et al. 2000; Sagar et al. 2003, 2004, 2006; Derdeyn et al. 2004; Keele et al. 2008 and many subsequent references) and transmitted viruses tend to be less glycosylated (Derdeyn et al. 2004; Chohan et al. 2005). In addition, 
The Antibody Response against HIV-1

the flurry of new MAbs isolated because of significant improvements in cohort characterization and antibody mapping methods, high-throughput neutralization screening and technological advances in immunoglobulin gene rescue have identified new targets on the HIV-1 envelope vulnerable to antibody attack with the promise of more to come. A number of studies on passive immunotherapy with these new more potent MAbs are being planned to test whether these antibodies can prevent infection in humans. Most human vaccine trials that focused on envelope immunogens have so far been disappointing in terms of NAb induction. However, the modest protection observed in the vaccine efficacy trial of ALVAC and AIDSVAX in Thailand (Rerks-Ngarm et al. 2009, and see O'Connell et al. 2011), using immunogens that do not elicit strong NAbs or T cell responses, has also renewed interest in examining other functions of antibodies. These activities include ADCC and ADVCI, as discussed above, as well as antibodies that prevent transcytosis across epithelial barriers (Shen et al. 2010) or mediate complement activation (Huber et al. 2006). The potential role of HIV-1-specific antibodies at mucosal sites in protection is poorly understood and is likely to be a topic of future studies. More basic research is needed into the full array of antibody-mediated effector functions in both infected populations as well as in ongoing vaccine trials in humans to determine the role of antibodies in protection.

\section{ACKNOWLEDGMENTS}

We would like to thank Dr. Penny Moore, Dr. Elin Gray, and Constantinos Kurt Wibmer for help with the figures and for critical reading of the manuscript.

\section{REFERENCES}

* Reference is also in this collection.

Baba TW, Liska V, Hofmann-Lehmann R, Vlasak J, Xu W, Ayehunie S, Cavacini LA, Posner MR, Katinger H, Stiegler G, et al. 2000. Human neutralizing monoclonal antibodies of the IgG1 subtype protect against mucosal simian-human immunodeficiency virus infection. Nat Med 6: 200-206.
Bailey JR, Lassen KG, Yang HC, Quinn TC, Ray SC, Blankson JN, Siliciano RF. 2006. Neutralizing antibodies do not mediate suppression of human immunodeficiency virus type 1 in elite suppressors or selection of plasma virus variants in patients on highly active antiretroviral therapy. J Virol 80: 4758-4770.

Banks ND, Kinsey N, Clements J, Hildreth JE. 2002. Sustained antibody-dependent cell-mediated cytotoxicity (ADCC) in SIV-infected macaques correlates with delayed progression to AIDS. AIDS Res Hum Retrov 18: $1197-1205$.

Barin F, Jourdain G, Brunet S, Ngo-Giang-Huong N, Weerawatgoompa S, Karnchanamayul W, Ariyadej S, Hansudewechakul R, Achalapong J, Yuthavisuthi P, et al. 2006. Revisiting the role of neutralizing antibodies in mother-to-child transmission of HIV-1. J Infect Dis 193: 1504-1511.

Barker E, Mackewicz CE, Reyes-Teran G, Sato A, Stranford SA, Fujimura SH, Christopherson C, Chang SY, Levy JA. 1998. Virological and immunological features of long-term human immunodeficiency virus-infected individuals who have remained asymptomatic compared with those who have progressed to acquired immunodeficiency syndrome. Blood 92: 3105-3114.

Beirnaert E, Nyambi P, Willems B, Heyndrickx L, Colebunders R, Janssens W, van der Groen G. 2000. Identification and characterization of sera from HIV-infected individuals with broad cross-neutralizing activity against group $\mathrm{M}$ (env clade A-H) and group O primary HIV-1 isolates. J Med Virol 62: 14-24.

Berke G. 1995. Unlocking the secrets of CTL and NK cells. Immunol Today 16: 343-346.

Binley J. 2009. Specificities of broadly neutralizing antiHIV-1 sera. Curr Opin HIVAIDS 4: 364-372.

Binley JM, Lybarger EA, Crooks ET, Seaman MS, Gray E, Davis KL, Decker JM, Wycuff D, Harris L, Hawkins N, et al. 2008. Profiling the specificity of neutralizing antibodies in a large panel of plasmas from patients chronically infected with human immunodeficiency virus type 1 subtypes B and C. J Virol 82: 11651-11668.

Blish CA, Dogan OC, Derby NR, Nguyen MA, Chohan B, Richardson BA, Overbaugh J. 2008. HIV-1 superinfection occurs despite relatively robust neutralizing antibody responses. J Virol 82: 12094-12103.

Blish CA, Jalalian-Lechak Z, Rainwater S, Nguyen MA, Dogan OC, Overbaugh J. 2009. Cross-subtype neutralization sensitivity despite monoclonal antibody resistance among early subtype A, C, and D HIV-1 envelope variants. J Virol 83: 7783-7788.

Bonsignori M, Hwang K. 2010. Immunoregulation of HIV-1 broadly neutralizing antibody responses: Deciphering maturation paths for antibody induction. In AIDS Vaccine 2010, p. A-153. Atlanta, Georgia.

Bosch KA, Rainwater S, Jaoko W, Overbaugh J. 2010. Temporal analysis of HIV envelope sequence evolution and antibody escape in a subtype A-infected individual with a broad neutralizing antibody response. Virology 398: 115-124.

Brouwer KC, Lal RB, Mirel LB, Yang C, van Eijk AM, Ayisi J, Otieno J, Nahlen BL, Steketee R, Lal AA, et al. 2004. Polymorphism of $\mathrm{Fc}$ receptor IIa for IgG in infants is 
J. Overbaugh and L. Morris

associated with susceptibility to perinatal HIV-1 infection. Aids 18: 1187-1194.

Brown BK, Wieczorek L, Sanders-Buell E, Rosa Borges A, Robb ML, Birx DL, Michael NL, McCutchan FE, Polonis VR. 2008. Cross-clade neutralization patterns among HIV-1 strains from the six major clades of the pandemic evaluated and compared in two different models. Virology 375: $529-538$.

Bunnik EM, Pisas L, van Nuenen AC, Schuitemaker H. 2008. Autologous neutralizing humoral immunity and evolution of the viral envelope in the course of subtype B human immunodeficiency virus type 1 infection. J Virol 82: 7932-7941.

Bures R, Morris L, Williamson C, Ramjee G, Deers M, Fiscus SA, Abdool-Karim S, Montefiori DC. 2002. Regional clustering of shared neutralization determinants on primary isolates of clade $\mathrm{C}$ human immunodeficiency virus type 1 from South Africa. J Virol 76: 2233-2244.

Burns DP, Desrosiers RC. 1991. Selection of genetic variants of simian immunodeficiency virus in persistently infected rhesus monkeys. J Virol 65: 1843-1854.

Burton DR, Stanfield RL, Wilson IA. 2005. Antibody vs. HIV in a clash of evolutionary titans. Proc Natl Acad Sci 102: $14943-14948$.

Cao Y, Qin L, Zhang L, Safrit J, Ho DD. 1995. Virologic and immunologic characterization of long-term survivors of human immunodeficiency virus type 1 infection [see comments]. N Engl J Med 332: 201-208.

Carotenuto P, Looij D, Keldermans L, de Wolf F, Goudsmit J. 1998. Neutralizing antibodies are positively associated with $\mathrm{CD}^{+}{ }^{+} \mathrm{T}$-cell counts and T-cell function in longterm AIDS-free infection. AIDS 12: 1591-1600.

Cecilia D, Kleeberger C, Munoz A, Giorgi JV, Zolla-Pazner S. 1999. A longitudinal study of neutralizing antibodies and disease progression in HIV-1-infected subjects. J Infect Dis 179: $1365-1374$

Chackerian B, Rudensey L, Overbaugh J. 1997. Specific Nlinked and O-linked glycosylation additions in the envelope V1 domain of SIV variants that evolve in the host alter neutralizing antibody recognition. J Virol 71: 7719-7727.

Chohan B, Lang D, Sagar M, Korber B, Lavreys L, Richardson B, Overbaugh J. 2005. Selection for human immunodeficiency virus type 1 envelope glycosylation variants with shorter V1-V2 loop sequences occurs during transmission of certain genetic subtypes and may impact viral RNA levels. J Virol 79: 6528-6531.

Chohan BH, Piantadosi A, Overbaugh J. 2010. HIV-1 Superinfection and its implications for vaccine design. Curr HIV Res 8: 596-601.

Conley AJ, Kessler J-A II, Boots LJ, McKenna PM, Schleif WA, Emini EA, Mark G-E III, Katinger H, Cobb EK, Lunceford SM, et al. 1996. The consequence of passive administration of an anti-human immunodeficiency virus type 1 neutralizing monoclonal antibody before challenge of chimpanzees with a primary virus isolate. $J$ Virol 70: 6751-6758.

Connick E, Marr DG, Zhang XQ, Clark SJ, Saag MS, Schooley RT, Curiel TJ. 1996. HIV-specific cellular and humoral immune responses in primary HIV infection. AIDS Res Hum Retrov 12: 1129-1140.
Corti D, Langedijk JP, Hinz A, Seaman MS, Vanzetta F, Fernandez-Rodriguez BM, Silacci C, Pinna D, Jarrossay D, Balla-Jhagjhoorsingh S, et al. 2010. Analysis of memory $\mathrm{B}$ cell responses and isolation of novel monoclonal antibodies with neutralizing breadth from HIV-1infected individuals. PLoS One 5: e8805.

Deeks SG, Schweighardt B, Wrin T, Galovich J, Hoh R, Sinclair E, Hunt P, McCune JM, Martin JN, Petropoulos CJ, et al. 2006. Neutralizing antibody responses against autologous and heterologous viruses in acute versus chronic human immunodeficiency virus (HIV) infection: Evidence for a constraint on the ability of HIV to completely evade neutralizing antibody responses. J Virol 80: 6155-6164.

Derdeyn CA, Decker JM, Bibollet-Ruche F, Mokili JL, Muldoon M, Denham SA, Heil ML, Kasolo F, Musonda R, Hahn BH, et al. 2004. Envelope-constrained neutralization-sensitive HIV-1 after heterosexual transmission. Science 303: 2019-2022.

Dhillon AK, Donners H, Pantophlet R, Johnson WE, Decker JM, Shaw GM, Lee FH, Richman DD, Doms RW, Vanham G, et al. 2007. Dissecting the neutralizing antibody specificities of broadly neutralizing sera from human immunodeficiency virus type 1 -infected donors. J Virol 81: 6548-6562.

Dickover R, Garratty E, Yusim K, Miller C, Korber B, Bryson Y. 2006. Role of maternal autologous neutralizing antibody in selective perinatal transmission of human immunodeficiency virus type 1 escape variants. J Virol 80: 6525-6533.

Doria-Rose NA, Klein RM, Manion MM, O'Dell S, Phogat A, Chakrabarti B, Hallahan CW, Migueles SA, Wrammert J, Ahmed R, et al. 2009. Frequency and phenotype of human immunodeficiency virus envelope-specific B cells from patients with broadly cross-neutralizing antibodies. J Virol 83: 188-199.

Dreja H, O'Sullivan E, Pade C, Greene KM, Gao H, Aubin K, Hand J, Isaksen A, D'Souza C, Leber W, et al. 2010. Neutralization activity in a geographically diverse East London cohort of human immunodeficiency virus type 1-infected patients: Clade $\mathrm{C}$ infection results in a stronger and broader humoral immune response than clade $\mathrm{B}$ infection. J Gen Virol 91: 2794-2803.

Emini EA, Schleif WA, Nunberg JH, Conley AJ, Eda Y, Tokiyoshi S, Putney SD, Matsushita S, Cobb KE, Jett CM, et al. 1992. Prevention of HIV-1 infection in chimpanzees by gp $120 \mathrm{~V} 3$ domain-specific monoclonal antibody. Nature 355: 728-730.

Euler Z, van Gils MJ, Bunnik EM, Phung P, Schweighardt B, Wrin T, Schuitemaker H. 2010. Cross-reactive neutralizing humoral immunity does not protect from HIV type 1 disease progression. J Infect Dis 201: 1045-1053.

Fauci AS, Johnston MI, Dieffenbach CW, Burton DR, Hammer SM, Hoxie JA, Martin M, Overbaugh J, Watkins DI, Mahmoud A, et al. 2008. HIV vaccine research: The way forward. Science 321: 530-532.

Florese RH, Demberg T, Xiao P, Kuller L, Larsen K, Summers LE, Venzon D, Cafaro A, Ensoli B, Robert-Guroff M. 2009. Contribution of nonneutralizing vaccine-elicited antibody activities to improved protective efficacy in rhesus macaques immunized with Tat/Env compared with multigenic vaccines. J Immunol 182: 3718-3727. 
The Antibody Response against HIV-1

Forthal DN, Landucci G, Daar ES. 2001a. Antibody from patients with acute human immunodeficiency virus (HIV) infection inhibits primary strains of HIV type 1 in the presence of natural-killer effector cells. J Virol 75: 6953-6961.

Forthal DN, Landucci G, Keenan B. 2001b. Relationship between antibody-dependent cellular cytotoxicity, plasma HIV type 1 RNA, and CD4 $4^{+}$lymphocyte count. AIDS Res Hum Retrov 17: 553-561.

Forthal DN, Gilbert PB, Landucci G, Phan T. 2007a. Recombinant gp120 vaccine-induced antibodies inhibit clinical strains of HIV-1 in the presence of Fc receptorbearing effector cells and correlate inversely with HIV infection rate. J Immunol 178: 6596-6603.

Forthal DN, Landucci G, Bream J, Jacobson LP, Phan TB, Montoya B. 2007b. FcyRIIa genotype predicts progression of HIV infection. J Immunol 179: 7916-7923.

Frost SD, Wrin T, Smith DM, Kosakovsky Pond SL, Liu Y, Paxinos E, Chappey C, Galovich J, Beauchaine J, Petropoulos CJ, et al. 2005. Neutralizing antibody responses drive the evolution of human immunodeficiency virus type 1 envelope during recent HIV infection. Proc Nat Acad Sci 102: 18514-18519.

Gilbert PB, Peterson ML, Follmann D, Hudgens MG, Francis DP, Gurwith M, Heyward WL, Jobes DV, Popovic V, Self SG, et al. 2005. Correlation between immunologic responses to a recombinant glycoprotein 120 vaccine and incidence of HIV-1 infection in a phase 3 HIV-1 preventive vaccine trial. J Infect Dis 191: 666-677.

Gnanakaran S, Lang D, Daniels M, Bhattacharya T, Derdeyn CA, Korber B. 2007. Clade-specific differences between human immunodeficiency virus type 1 clades $\mathrm{B}$ and $\mathrm{C}$ Diversity and correlations in C3-V4 regions of gp120. J Virol 81: 4886-4891.

Gomez-Roman VR, Patterson LJ, Venzon D, Liewehr D, Aldrich K, Florese R, Robert-Guroff M. 2005. Vaccineelicited antibodies mediate antibody-dependent cellular cytotoxicity correlated with significantly reduced acute viremia in rhesus macaques challenged with SIVmac251. J Immunol 174: 2185-2189.

Gorny MK, Wang XH, Williams C, Volsky B, Revesz K, Witover B, Burda S, Urbanski M, Nyambi P, Krachmarov C, et al. 2009. Preferential use of the VH5-51 gene segment by the human immune response to code for antibodies against the V3 domain of HIV-1. Mol Immunol 46: 917-926.

Gray ES, Moore PL, Choge IA, Decker JM, Bibollet-Ruche F, Li H, Leseka N, Treurnicht F, Mlisana K, Shaw GM, et al. 2007. Neutralizing antibody responses in acute human immunodeficiency virus type 1 subtype $\mathrm{C}$ infection. J Virol 81: 6187-6196.

Gray ES, Madiga MC, Moore PL, Mlisana K, Abdool Karim SS, Binley JM, Shaw GM, Mascola JR, Morris L. 2009a. Broad neutralization of human immunodeficiency virus type 1 mediated by plasma antibodies against the gp41 membrane proximal external region. J Virol 83: 1126511274.

Gray ES, Taylor N, Wycuff D, Moore PL, Tomaras GD, Wibmer CK, Puren A, DeCamp A, Gilbert PB, Wood B, et al. 2009b. Antibody specificities associated with neutralization breadth in plasma from human immunodeficiency virus type 1 subtype C-infected blood donors. J Virol 83: 8925-8937.

Gray ES, Madiga MC, Hermanus T, Moore PL, Wibmer CK, Tumba NL, Werner L, Mlisana K, Sibeko S, Williamson C, et al. 2011. HIV-1 neutralization breadth develops incrementally over 4 years and is associated with $\mathrm{CD} 4^{+} \mathrm{T}$ cell decline and high viral load during acute infection. J Virol 85: 4828-4840.

Harrer T, Harrer E, Kalams SA, Elbeik T, Staprans SI, Feinberg MB, Cao Y, Ho DD, Yilma T, Caliendo AM, et al. 1996. Strong cytotoxic T cell and weak neutralizing antibody responses in a subset of persons with stable nonprogressing HIV type 1 infection. AIDS Res Hum Retrov 12: 585-592.

Hasselrot K, Saberg P, Hirbod T, Soderlund J, Ehnlund M, Bratt G, Sandstrom E, Broliden K. 2009. Oral HIVexposure elicits mucosal HIV-neutralizing antibodies in uninfected men who have sex with men. AIDS 23: 329-333.

Hengel RL, Kennedy MS, Steketee RW, Thea DM, Abrams EJ, Lambert G, McDougal JS. 1998. Neutralizing antibody and perinatal transmission of human immunodeficiency virus type 1 . New York City Perinatal HIV Transmission Collaborative Study Group. AIDS Res Hum Retrov 14: 475-481.

Herrera C, Spenlehauer C, Fung MS, Burton DR, Beddows S, Moore JP. 2003. Nonneutralizing antibodies to the CD4-binding site on the gp120 subunit of human immunodeficiency virus type 1 do not interfere with the activity of a neutralizing antibody against the same site. J Virol 77: 1084-1091.

Hessell AJ, Hangartner L, Hunter M, Havenith CE, Beurskens FJ, Bakker JM, Lanigan CM, Landucci G, Forthal DN, Parren PW, et al. 2007. Fc receptor but not complement binding is important in antibody protection against HIV. Nature 449: 101-104.

Hessell AJ, Poignard P, Hunter M, Hangartner L, Tehrani DM, Bleeker WK, Parren PW, Marx PA, Burton DR. 2009. Effective, low-titer antibody protection against low-dose repeated mucosal SHIV challenge in macaques. Nat Med 15: 951-954.

Hidajat R, Xiao P, Zhou Q, Venzon D, Summers LE, Kalyanaraman VS, Montefiori DC, Robert-Guroff M. 2009 Correlation of vaccine-elicited systemic and mucosal nonneutralizing antibody activities with reduced acute viremia following intrarectal simian immunodeficiency virus SIVmac251 challenge of rhesus macaques. J Virol 83: $791-801$.

Hirbod T, Kaul R, Reichard C, Kimani J, Ngugi E, Bwayo JJ, Nagelkerke N, Hasselrot K, Li B, Moses S, et al. 2008. HIV-neutralizing immunoglobulin A and HIV-specific proliferation are independently associated with reduced HIV acquisition in Kenyan sex workers. AIDS 22: 727 735.

Honnen WJ, Krachmarov C, Kayman SC, Gorny MK, ZollaPazner S, Pinter A. 2007. Type-specific epitopes targeted by monoclonal antibodies with exceptionally potent neutralizing activities for selected strains of human immunodeficiency virus type 1 map to a common region of the V2 domain of gp120 and differ only at single positions from the clade B consensus sequence. J Virol 81: $1424-1432$. 
J. Overbaugh and L. Morris

Huang CC, Tang M. 2005. Structure of a V3-containing HIV-1 gp120 core. Science 310: 1025-1028.

Huang CC, Venturi M, Majeed S, Moore MJ, Phogat S, Zhang MY, Dimitrov DS, Hendrickson WA, Robinson J, Sodroski J, et al. 2004. Structural basis of tyrosine sulfation and VH-gene usage in antibodies that recognize the HIV type 1 coreceptor-binding site on gp120. Proc Natl Acad Sci 101: 2706-2711.

Huang KH, Bonsall D, Katzourakis A, Thomson EC, Fidler SJ, Main J, Muir D, Weber JN, Frater AJ, Phillips RE, et al. 2010. B-cell depletion reveals a role for antibodies in the control of chronic HIV-1 infection. Nat Commun 1: 102.

Huber M, Fischer M, Misselwitz B, Manrique A, Kuster H, Niederost B, Weber R, von Wyl V, Gunthard HF, Trkola A. 2006. Complement lysis activity in autologous plasma is associated with lower viral loads during the acute phase of HIV-1 infection. PLoS Med 3: e441.

Husson RN, Lan Y, Kojima E, Venzon D, Mitsuya H, McIntosh K. 1995. Vertical transmission of human immunodeficiency virus type 1: Autologous neutralizing antibody, virus load, and virus phenotype. J Pediatr 126: 865-871.

Johnson PR, Hamm TE, Goldstein S, Kitov S, Hirsch VM. 1991. The genetic fate of molecularly cloned simian immunodeficiency virus in experimentally infected macaques. Virology 185: 217-228.

Kagi D, Vignaux F, Ledermann B, Burki K, Depraetere V, Nagata S, Hengartner H, Golstein P. 1994. Fas and perforin pathways as major mechanisms of T cell-mediated cytotoxicity. Science 265: 528-530.

Karlsson Hedestam GB, Fouchier RA, Phogat S, Burton DR, Sodroski J, Wyatt RT. 2008. The challenges of eliciting neutralizing antibodies to HIV-1 and to influenza virus. Nat Rev Microbiol 6: 143-155.

Keele BF, Giorgi EE, Salazar-Gonzalez JF, Decker JM, Pham KT, Salazar MG, Sun C, Grayson T, Wang S, Li H, et al. 2008. Identification and characterization of transmitted and early founder virus envelopes in primary HIV-1 infection. Proc Natl Acad Sci 105: 7552-7557.

Kirchherr JL, Hamilton J, Lu X, Gnanakaran S, Muldoon M, Daniels M, Kasongo W, Chalwe V, Mulenga C, Mwananyanda L, et al. 2011. Identification of amino acid substitutions associated with neutralization phenotype in the human immunodeficiency virus type-1 subtype C gp120. Virology 409: 163-174.

Kliks SC, Wara DW, Landers DV, Levy JA. 1994. Features of HIV-1 that could influence maternal-child transmission. JAMA 272: 467-474.

Kwong PD, Wilson IA. 2009. HIV-1 and influenza antibodies: Seeing antigens in new ways. Nat Immunol 10: $573-$ 578.

* Kwong PD, Mascola JR, Nabel GJ. 2011. Rational design of vaccines to elicit broadly neutralizing antibodies to HIV-1. Cold Spring Harb Perspect Med doi: 10.1101/ cshperspect.a007278.

Laird ME, Igarashi T, Martin MA, Desrosiers RC. 2008. Importance of the V1/V2 loop region of simian-human immunodeficiency virus envelope glycoprotein gp120 in determining the strain specificity of the neutralizing antibody response. J Virol 82: 11054-11065.

Lambotte O, Ferrari G, Moog C, Yates NL, Liao HX, Parks RJ, Hicks CB, Owzar K, Tomaras GD, Montefiori DC, et al. 2009. Heterogeneous neutralizing antibody and antibody-dependent cell cytotoxicity responses in HIV-1 elite controllers. AIDS 23: 897-906.

Legrand E, Pellegrin I, Neau D, Pellegrin JL, Ragnaud JM, Dupon M, Guillemain B, Fleury HJ. 1997. Course of specific T lymphocyte cytotoxicity, plasma and cellular viral loads, and neutralizing antibody titers in 17 recently seroconverted HIV type 1-infected patients. AIDS Res Hum Retrov 13: 1383-1394.

Li M, Salazar-Gonzalez JF, Derdeyn CA, Morris L, Williamson C, Robinson JE, Decker JM, Li Y, Salazar MG, Polonis VR, et al. 2006. Genetic and neutralization properties of subtype $\mathrm{C}$ human immunodeficiency virus type 1 molecular env clones from acute and early heterosexually acquired infections in Southern Africa. J Virol 80: 1177611790.

Li Y, Svehla K, Louder MK, Wycuff D, Phogat S, Tang M, Migueles SA, Wu X, Phogat A, Shaw GM, et al. 2009. Analysis of neutralization specificities in polyclonal sera derived from human immunodeficiency virus type 1infected individuals. J Virol 83: 1045-1059.

* Lifson JD, Haigwood NL. 2011. Lessons in nonhuman primate models for AIDS vaccine research: From minefields to milestones. Cold Spring Harb Perspect Med doi: 10.1101/cshperspect.a007310.

Long EM, Martin HL Jr, Kreiss JK, Rainwater SM, Lavreys L, Jackson DJ, Rakwar J, Mandaliya K, Overbaugh J. 2000. Gender differences in HIV-1 diversity at time of infection. Nat Med 6: 71-75.

Loomis-Price LD, Cox JH, Mascola JR, VanCott TC, Michael NL, Fouts TR, Redfield RR, Robb ML, Wahren B, Sheppard HW, et al. 1998. Correlation between humoral responses to human immunodeficiency virus type 1 envelope and disease progression in early-stage infection. J Infect Dis 178: 1306-1316.

Lynch JN, Nduati R, Blish C, Richardson BA, Mabuka J, Lechak Z, John-Stewart GC, Overbaugh J. 2011. The breadth and potency of passively acquired HIV- specific neutralizing antibodies does not correlate with risk of infant HIV infection. J Virol 85: 5252-5261.

Mahalanabis M, Jayaraman P, Miura T, Pereyra F, Chester EM, Richardson B, Walker B, Haigwood NL. 2009. Continuous viral escape and selection by autologous neutralizing antibodies in drug-naive human immunodeficiency virus controllers. J Virol 83: 662-672.

Mascola JR, Lewis MG, Stiegler G, Harris D, VanCott TC, Hayes D, Louder MK, Brown CR, Sapan CV, Frankel SS, et al. 1999. Protection of macaques against pathogenic simian/human immunodeficiency virus $89.6 \mathrm{PD}$ by passive transfer of neutralizing antibodies. $J$ Virol 73: 4009-4018.

Mascola JR, Stiegler G, VanCott TC, Katinger H, Carpenter CB, Hanson CE, Beary H, Hayes D, Frankel SS, Birx DL, et al. 2000. Protection of macaques against vaginal transmission of a pathogenic HIV-1/SIV chimeric virus by passive infusion of neutralizing antibodies. Nat Med 6: 207-210.

Mc Cann CM, Song RJ, Ruprecht RM. 2005. Antibodies: Can they protect against HIV infection? Curr Drug Targets Infect Disord 5: 95-111.

McNearney T, Hornickova Z, Markham R, Birdwell A, Arens M, Saah A, Ratner L. 1992. Relationship of human 
The Antibody Response against HIV-1

immunodeficiency virus type 1 sequence heterogeneity to stage of disease. Proc Natl Acad Sci 89: 10247-10251.

Miller CJ, Genesca M, Abel K, Montefiori D, Forthal D, Bost K, Li J, Favre D, McCune JM. 2007. Antiviral antibodies are necessary for control of simian immunodeficiency virus replication. J Virol 81: 5024-5035.

Moir S, Fauci AS. 2009. B cells in HIV infection and disease. Nat Rev Immunol 9: 235-245.

Montefiori DC, Pantaleo G, Fink LM, Zhou JT, Zhou JY, Bilska M, Miralles GD, Fauci AS. 1996. Neutralizing and infection-enhancing antibody responses to human immunodeficiency virus type 1 in long-term nonprogressors. J Infect Dis 173: 60-67.

Moog C, Fleury HJA, Pellegrin I, Kirn A, Aubertin AM. 1997. Autologous and heterlogous neutralizing antibody responses following initial seroconversion in human immunodeficiency virus type 1-infected individuals. J Virol 71: 3734-3741.

Moore JP, Cao Y, Ho DD, Koup RA. 1994. Development of the anti-gp120 antibody response during seroconversion to human immunodeficiency virus type 1 . J Virol 68: $5142-5155$.

Moore JP, Cao Y, Leu J, Qin L, Korber B, Ho DD. 1996. Interand intraclade neutralization of human immunodeficiency virus type 1: Genetic clades do not correspond to neutralization serotypes but partially correspond to gp120 antigenic serotypes. J Virol 70: 427-444.

Moore PL, Gray ES, Morris L. 2009a. Specificity of the autologous neutralizing antibody response. Curr Opin HIV AIDS 4: 358-363.

Moore PL, Ranchobe N, Lambson BE, Gray ES, Cave E, Abrahams MR, Bandawe G, Mlisana K, Abdool Karim SS, Williamson C, et al. 2009b. Limited neutralizing antibody specificities drive neutralization escape in early HIV-1 subtype C infection. PLoS Pathog 5: e1000598.

* O’Connell RJ, Kim JH, Corey L, Michael NL. 2011. Human immunodeficiency virus vaccine trials. Cold Spring Harb Perspect Med doi: 10.1101/cshperspect.a007351.

Overbaugh J, Rudensey LM. 1992. Alterations in potential sites for glycosylation predominate during evolution of the simian immunodeficiency virus envelope gene in macaques. J Virol 66: 5937-5948.

Overbaugh J, Rudensey LM, Papenhausen MD, Benveniste RE, Morton WR. 1991. Variation in simian immunodeficiency virus env is confined to $\mathrm{V} 1$ and $\mathrm{V} 4$ during progression to simian AIDS. J Virol 65: 7025-7031.

Parren PW, Marx PA, Hessell AJ, Luckay A, Harouse J, Cheng-Mayer C, Moore JP, Burton DR. 2001. Antibody protects macaques against vaginal challenge with a pathogenic R5 simian/human immunodeficiency virus at serum levels giving complete neutralization in vitro. J Virol 75: 8340-8347.

Pereyra F, Addo MM, Kaufmann DE, Liu Y, Miura T, Rathod A, Baker B, Trocha A, Rosenberg R, Mackey E, et al. 2008. Genetic and immunologic heterogeneity among persons who control HIV infection in the absence of therapy. J Infect Dis 197: 563-571.

Piantadosi A, Panteleeff D, Blish CA, Baeten JM, Jaoko W, McClelland RS, Overbaugh J. 2009. HIV-1 neutralizing antibody breadth is affected by factors early in infection, but does not influence disease progression. J Virol 83: 10269-10274.
Pilgrim AK, Pantaleo G, Cohen OJ, Fink LM, Zhou JY, Zhou JT, Bolognesi DP, Fauci AS, Montefiori DC. 1997. Neutralizing antibody responses to human immunodeficiency virus type 1 in primary infection and long-termnonprogressive infection. J Infect Dis 176: 924-932.

Pinter A, Honnen WJ, He Y, Gorny MK, Zolla-Pazner S, Kayman SC. 2004. The V1/V2 domain of gp120 is a global regulator of the sensitivity of primary human immunodeficiency virus type 1 isolates to neutralization by antibodies commonly induced upon infection. J Virol 78: $5205-5215$.

Poss M, Martin HL, Kreiss JK, Granville L, Chohan B, Nyange P, Mandaliya K, Overbaugh J. 1995. Diversity in virus populations from genital secretions and peripheral blood from women recently infected with human immunodeficiency virus type 1. J Virol 69: 8118-8122.

Prince AM, Reesink H, Pascual D, Horowitz B, Hewlett I, Murthy KK, Cobb KE, Eichberg JW. 1991. Prevention of HIV infection by passive immunization with HIV immunoglobulin. AIDS Res Hum Retrov 7: 971-973.

Rerks-Ngarm S, Pitisuttithum P, Nitayaphan S, Kaewkungwal J, Chiu J, Paris R, Premsri N, Namwat C, de Souza M, Adams E, et al. 2009. Vaccination with ALVAC and AIDSVAX to prevent HIV-1 infection in Thailand. New Engl J Med 361: 2209-2220.

Richman DD, Wrin T, Little SJ, Petropoulos CJ. 2003. Rapid evolution of the neutralizing antibody response to HIV type 1 infection. Proc Natl Acad Sci 100: 4144-4149.

Rodriguez SK, Sarr AD, MacNeil A, Thakore-Meloni S, Gueye-Ndiaye A, Traore I, Dia MC, Mboup S, Kanki PJ. 2007. Comparison of heterologous neutralizing antibody responses of human immunodeficiency virus type 1 (HIV-1)- and HIV-2-infected Senegalese patients: Distinct patterns of breadth and magnitude distinguish HIV-1 and HIV-2 infections. J Virol 81: 5331-5338.

Rong R, Bibollet-Ruche F, Mulenga J, Allen S, Blackwell JL, Derdeyn CA. 2007. Role of V1V2 and other human immunodeficiency virus type 1 envelope domains in resistance to autologous neutralization during clade $\mathrm{C}$ infection. J Virol 81: 1350-1359.

Rong R, Li B, Lynch RM, Haaland RE, Murphy MK, Mulenga J, Allen SA, Pinter A, Shaw GM, Hunter E, et al. 2009. Escape from autologous neutralizing antibodies in acute/early subtype C HIV-1 infection requires multiple pathways. PLoS Pathog 5: e1000594.

Russell JH, Ley TJ. 2002. Lymphocyte-mediated cytotoxicity. Annu Rev Immunol 20: 323-370.

Sabin C, Corti D, Buzon V, Seaman MS, Lutje Hulsik D, Hinz A, Vanzetta F, Agatic G, Silacci C, Mainetti L, et al. 2010. Crystal structure and size-dependent neutralization properties of HK20, a human monoclonal antibody binding to the highly conserved heptad repeat 1 of gp41. PLoS Pathog 6: e1001195.

Sagar M. 2010. HIV-1 transmission biology: Selection and characteristics of infecting viruses. J Infect Dis 202 (Suppl 2): S289-S296.

Sagar M, Lavreys L, Baeten JM, Richardson BA, Mandaliya K, Ndinya-Achola JO, Kreiss JK, Overbaugh J. 2003. Identification of modifiable factors that affect the genetic diversity of the transmitted HIV-1 population. AIDS 18: $1-5$. 
Sagar M, Kirkegaard E, Long EM, Celum C, Buchbinder S, Daar ES, Overbaugh J. 2004. Human immunodeficiency virus type 1 (HIV-1) diversity at time of infection is not restricted to certain risk groups or specific HIV-1 subtypes. J Virol 78: 7279-7283.

Sagar M, Kirkegaard E, Lavreys L, Overbaugh J. 2006. Diversity in HIV-1 envelope V1-V3 sequences early in infection reflects sequence diversity throughout the HIV-1 genome but does not predict the extent of sequence diversity during chronic infection. AIDS Res Hum Retrov 22: $430-437$.

Samleerat T, Thenin S, Jourdain G, Ngo-Giang-Huong N Moreau A, Leechanachai P, Ithisuknanth J, Pagdi K, Wannarit P, Sangsawang S, et al. 2009. Maternal neutralizing antibodies against a CRF01_AE primary isolate are associated with a low rate of intrapartum HIV-1 transmission. Virology 387: 388-394.

Sather DN, Armann J, Ching LK, Mavrantoni A, Sellhorn G, Caldwell Z, Yu X, Wood B, Self S, Kalams S, et al. 2009. Factors associated with the development of cross-reactive neutralizing antibodies during Human Immunodeficiency Virus Type 1 infection. J Virol 83: 757-769.

Scarlatti G, Albert J, Rossi P, Hodara V, Biraghi P, Muggiasca L, Fenyo EM. 1993a. Mother-to-child transmission of human immunodeficiency virus type 1: Correlation with neutralizing antibodies against primary isolates. $J$ Infect Dis 168: 207-210.

Scarlatti G, Leitner T, Hodara V, Halapi E, Rossi P, Albert J, Fenyo EM. 1993b. Neutralizing antibodies and viral characteristics in mother-to-child transmission of HIV-1. Aids 7 (Suppl 2): S45-S48.

Scheid JF, Mouquet H, Feldhahn N, Seaman MS, Velinzon K, Pietzsch J, Ott RG, Anthony RM, Zebroski H, Hurley A, et al. 2009. Broad diversity of neutralizing antibodies isolated from memory B cells in HIV-infected individuals. Nature 458: 636-640.

Schmitz JE, Kuroda MJ, Santra S, Simon MA, Lifton MA, Lin W, Khunkhun R, Piatak M, Lifson JD, Grosschupff G, et al. 2003. Effect of humoral immune responses on controlling viremia during primary infection of rhesus monkeys with simian immunodeficiency virus. J Virol 77: $2165-2173$.

Seaman MS, Janes H, Hawkins N, Grandpre LE, Devoy C, Giri A, Coffey RT, Harris L, Wood B, Daniels MG, et al. 2010. Tiered categorization of a diverse panel of HIV-1 Env pseudoviruses for assessment of neutralizing antibodies. J Virol 84: 1439-1452.

* Shaw GM, Hunter E. 2011. HIV transmission. Cold Spring Harb Perspect Med doi: 10.1101/cshperspect.a006965.

Shen R, Drelichman ER, Bimczok D, Ochsenbauer C, Kappes JC, Cannon JA, Tudor D, Bomsel M, Smythies LE, Smith PD. 2010. GP41-specific antibody blocks cell-free HIV type 1 transcytosis through human rectal mucosa and model colonic epithelium. J Immunol 184: $3648-3655$.

Shibata R, Igarashi T, Haigwood N, Buckler-White A, Ogert R, Ross W, Willey R, Cho MW, Martin MA. 1999. Neutralizing antibody directed against the HIV-1 envelope glycoprotein can completely block HIV-1/SIV chimeric virus infections of macaque monkeys. Nat Med 5: 204-210.
Simek MD, Rida W, Priddy FH, Pung P, Carrow E, Laufer DS, Lehrman JK, Boaz M, Tarragona-Fiol T, Miiro G, et al. 2009. Human immunodeficiency virus type 1 elite neutralizers: Individuals with broad and potent neutralizing activity identified by using a high-throughput neutralization assay together with an analytical selection algorithm. J Virol 83: 7337-7348.

Smith DM, Strain MC, Frost SDW, Pillai SK, Wong JK, Wrin T, Petropolous CJ, Daar ES, Little SJ, Richman DD. 2006. Lack of nuetralizaing antibody response to HIV-1 prediposes to superinfection. Virology 355: 1-5.

Stamatatos L, Morris L, Burton DR, Mascola JR. 2009. Neutralizing antibodies generated during natural HIV-1 infection: Good news for an HIV-1 vaccine? Nat Med 15: $866-870$.

Tang H, Robinson JE, Gnanakaran S, Li M, Rosenberg ES, Perez LG, Haynes BF, Liao HX, Labranche CC, Korber BT, et al. 2011. Epitopes immediately below the base of the V3 loop of gp120 as targets for the initial autologous neutralizing antibody response in two HIV-1 subtype Binfected individuals. J Virol 85: 9286-9299.

Tomaras G, Binley J. 2010. Epitope specificities of elite neutralizing sera from HIV-1-infected individuals. In Abstracts from AIDS Vaccine 2010, p. A-24. Atlanta, Georgia.

Tomaras GD, Yates NL, Liu P, Qin L, Fouda GG, Chavez LL, Decamp AC, Parks RJ, Ashley VC, Lucas JT, et al. 2008. Initial B-cell responses to transmitted human immunodeficiency virus type 1: Virion-binding immunoglobulin $\mathrm{M}$ (IgM) and $\operatorname{IgG}$ antibodies followed by plasma anti-gp41 antibodies with ineffective control of initial viremia. J Virol 82: 12449-12463.

Toran JL, Kremer L, Sanchez-Pulido L, de Alboran IM, del Real G, Llorente M, Valencia A, de Mon MA, Martinez AC. 1999. Molecular analysis of HIV-1 gp120 antibody response using isotype IgM and $\mathrm{IgG}$ phage display libraries from a long-term non-progressor HIV-1-infected individual. Eur J Immunol 29: 2666-2675.

Trkola A, Purtscher M, Muster T, Ballaun C, Buchacher A, Sullivan N, Srinivasan K, Sodroski J, Moore JP, Katinger H. 1996. Human monoclonal antibody 2G12 defines a distinctive neutralization epitope on the gp120 glycoprotein of human immunodeficiency virus type 1. J Virol 70: $1100-1108$.

Trkola A, Kuster H, Rusert P, von Wyl V, Leemann C, Weber R, Stiegler G, Katinger H, Joos B, Gunthard HF. 2008. In vivo efficacy of human immunodeficiency virus neutralizing antibodies: Estimates for protective titers. J Virol 82: $1591-1599$.

Walker LM, Chan-Hui P. 2010. High through-put functional screening of activated B cells from 4 African elite neutralizers yields a panel of novel broadly neutralizing antibodies. In Abstracts from AIDS Vaccine 2010, pp. A-149-A-150. Atlanta, Georgia.

Walker LM, Phogat SK, Chan-Hui PY, Wagner D, Phung P, Goss JL, Wrin T, Simek MD, Fling S, Mitcham JL, et al. 2009. Broad and potent neutralizing antibodies from an African donor reveal a new HIV-1 vaccine target. Science 326: $285-289$.

Wei X, Decker JM, Wang S, Hui H, Kappes JC, Wu X, Salazar-Gonzalez JF, Salazar MG, Kilby JM, Saag MS, 
The Antibody Response against HIV-1

et al. 2003. Antibody neutralization and escape by HIV-1. Nature 422: 307-312.

Wolinsky SM, Wike CM, Korber BT, Hutto C, Parks WP, Rosenblum LL, Kunstman KJ, Furtado MR, Munoz JL. 1992. Selective transmission of human immunodeficiency virus type-1 variants from mothers to infants. Science 255: 1134-1137.

Wu X, Wang C. 2010. Characterization of HIV-1 envelope variants from slow progressors who developed broadly neutralizing CD4-binding site antibodies against HIV-1. In Abstracts from AIDS Vaccine 2010, p. A-53. Atlanta, Georgia.

Wu X, Parast AB, Richardson BA, Nduati R, John-Stewart G, Mbori-Ngacha D, Rainwater SM, Overbaugh J. 2006. Neutralization escape variants of human immunodeficiency virus type 1 are transmitted from mother to infant. J Virol 80: 835-844.

Wu X, Yang ZY, Li Y, Hogerkorp CM, Schief WR, Seaman MS, Zhou T, Schmidt SD, Wu L, Xu L, et al. 2010 Rational design of envelope identifies broadly neutralizing human monoclonal antibodies to HIV-1. Science 329: 856-861.

Xiao X, Chen W, Feng Y, Zhu Z, Prabakaran P, Wang Y, Zhang MY, Longo NS, Dimitrov DS. 2009. Germline-like predecessors of broadly neutralizing antibodies lack measurable binding to HIV-1 envelope glycoproteins: Implications for evasion of immune responses and design of vaccine immunogens. Biochem Biophys Res Commun 390: 404-409.

Xiao P, Zhao J, Patterson LJ, Brocca-Cofano E, Venzon D, Kozlowski PA, Hidajat R, Demberg T, Robert-Guroff M. 2010. Multiple vaccine-elicited nonneutralizing antienvelope antibody activities contribute to protective efficacy by reducing both acute and chronic viremia following simian/human immunodeficiency virus SHIV89.6P challenge in rhesus macaques. J Virol 84: 7161-7173.

Zhang LQ, MacKenzie P, Cleland A, Holmes EC, Brown AJ, Simmonds P. 1993. Selection for specific sequences in the external envelope protein of human immunodeficiency virus type 1 upon primary infection. J Virol 67: 33453356.

Zhang YJ, Fracasso C, Fiore JR, Bjorndal A, Angarano G, Gringeri A, Fenyo EM. 1997. Augmented serum neutralizing activity against primary human immunodeficiency virus type 1 (HIV-1) isolates in two groups of HIV-1-infected long-term nonprogressors. J Infect Dis 176: $1180-1187$

Zhang H, Rola M, West JT, Tully DC, Kubis P, He J, Kankasa C, Wood C. 2010. Functional properties of the HIV-1 subtype $\mathrm{C}$ envelope glycoprotein associated with mother-to-child transmission. Virology 400: 164-174.

Zhou T, Xu L, Dey B, Hessell AJ, Van Ryk D, Xiang SH, Yang X, Zhang MY, Zwick MB, Arthos J, et al. 2007. Structural definition of a conserved neutralization epitope on HIV1 gp120. Nature 445: 732-737.

Zhu Z, Qin HR. 2010. New broadly neutralizing human monoclonal antibodies targeting the 2F5 epitope. In Abstracts from AIDS Vaccine 2010, pp. A-14-A-15. Atlanta, Georgia.

Zhu T, Mo H, Wang N, Nam DS, Cao Y, Koup RA, Ho DD. 1993. Genotypic and phenotypic characterization of HIV-1 in patients with primary infection. Science 261: 1179-1181. 


\section{$\&_{\mathrm{CSH}}^{\infty} \&$ Cold Spring Harbor

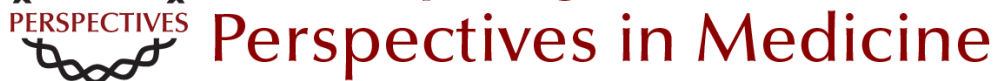

\section{The Antibody Response against HIV-1}

Julie Overbaugh and Lynn Morris

Cold Spring Harb Perspect Med 2012; doi: 10.1101/cshperspect.a007039 originally published online November 1, 2011

\section{Subject Collection HIV}

HIV Pathogenesis: Dynamics and Genetics of

Viral Populations and Infected Cells John Coffin and Ronald Swanstrom

Human Immunodeficiency Virus Vaccine Trials Robert J. O'Connell, Jerome H. Kim, Lawrence Corey, et al.

HIV Transmission George M. Shaw and Eric Hunter

Novel Cell and Gene Therapies for HIV James A. Hoxie and Carl H. June

\section{Behavioral and Biomedical Combination}

Strategies for HIV Prevention Linda-Gail Bekker, Chris Beyrer and Thomas C. Quinn

HIV-1 Assembly, Budding, and Maturation Wesley I. Sundquist and Hans-Georg Kräusslich

HIV-1 Assembly, Budding, and Maturation Wesley I. Sundquist and Hans-Georg Kräusslich

Lessons in Nonhuman Primate Models for AIDS Vaccine Research: From Minefields to Milestones Jeffrey D. Lifson and Nancy L. Haigwood
HIV-1 Pathogenesis: The Virus Ronald Swanstrom and John Coffin

The T-Cell Response to HIV Bruce Walker and Andrew McMichael

HIV-1 Reverse Transcription Wei-Shau Hu and Stephen H. Hughes

HIV Pathogenesis: The Host A.A. Lackner, Michael M. Lederman and Benigno Rodriguez

HIV: Cell Binding and Entry Craig B. Wilen, John C. Tilton and Robert W. Doms

Innate Immune Control of HIV Mary Carrington and Galit Alter

HIV DNA Integration Robert Craigie and Frederic D. Bushman

HIV-1-Related Central Nervous System Disease: Current Issues in Pathogenesis, Diagnosis, and Treatment Serena Spudich and Francisco González-Scarano

For additional articles in this collection, see http://perspectivesinmedicine.cshlp.org/cgi/collection/ 